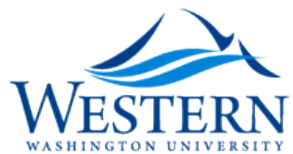

Western Washington University

Western CEDAR

$12-1996$

\title{
Thoreau's Critique of the American Pastoral in $A$ Week
}

Ning Yu

Western Washington University, ning.yu@wwu.edu

Follow this and additional works at: https:// cedar.wwu.edu/english_facpubs

Part of the English Language and Literature Commons

\section{Recommended Citation}

Yu, Ning, "Thoreau's Critique of the American Pastoral in A Week" (1996). English Faculty and Staff Publications. 5. https://cedar.wwu.edu/english_facpubs/5

This Article is brought to you for free and open access by the English at Western CEDAR. It has been accepted for inclusion in English Faculty and Staff Publications by an authorized administrator of Western CEDAR. For more information, please contact westerncedar@wwu.edu. 


\title{
Thoreau's Critique of the American Pastoral in $A$ Week
}

\author{
NING YU
}

ARgely because of Thoreau's statement
that he wrote A Week on the Concord and Merrimack Rivers as a "paean to the departed soul," few critics question a consensus that Thoreau's first book is a pastoral elegy to his brother John. ${ }^{1}$ Sherman Paul reads $A$ Week as Thoreau's attempt to achieve a "communion with the eternal" and to be part of the tradition of "the eternally timeless." Reading $A$ Week as Thoreau's "memorial tribute to John," Walter Harding identifies the timeless tradition with "the tradition of the pastoral elegy." Linck C. Johnson, more recently, compares

(C) 1996 by The Regents of the University of California

1 See The Correspondence of Henry David Thoreau, ed. Walter Harding and Carl Bode (New York: New York Univ. Press, 1958), p. 65. The American pastoral tradition discussed in this essay refers to a tendency to view America as an idealized place of pure and carefree existence in rural settings. In The Machine in the Garden: Technology and the Pastoral Ideal in America (New York: Oxford Univ. Press, 1964), Leo Marx studies this tendency as two distinct types of pastoralism: the sentimental and the imaginary. This trend has also been discussed under different names such as "agrarianism," "rural values," "the agrarian myth," the "Old Republican idyll," and "the myth of the garden" by such scholars as Richard Hofstadter, Marvin Meyers, Henry Nash Smith, Lawrence Buell, and Glen Love. Often embodied in "an image of a natural landscape, a terrain either unspoiled or, if cultivated, rural" (Marx, p. 9), the American pastoral can be found in the works of scores of American authors with which Thoreau was familiar, including John Smith's promotional description of New England, William Bartram's "little promontory" on the west bank of a Florida river, Jean de Crevecoeur's "too-goodto-be-true" American farms, and Timothy Dwight's "flourishing village" of the idealized Greenfield Hill. 
A Week with Milton's "Lycidas" and argues that Thoreau's book is "one of the most ambitious of all pastoral elegies, in which Thoreau, like Milton, sought to assuage his grief for the loss of a companion of his youth." To do this, Thoreau used a "basic strategy of the pastoral elegy," placing John's "sudden and seemingly "accidental" " death "within the annual cycle of the decay and regeneration." For Richard Lebeaux, A Week is "in part an affectionate elegy to John" attempting to resolve John's death in the pastoral "golden age," and in part self-therapy attempting to relive "the lost Eden of the prerivalry and preoedipal past." H. Daniel Peck postulates that in A Week Thoreau tries to redeem his brother's death by "killing time."

That $A$ Week contains pastoral elements does not necessarily mean it is a pastoral book. As a generic category, the pastoral elegy tends to limit Thoreau's first book to a personal scope. Read as such, $A$ Week seems consistent with Thoreau's request for every author to write "a simple and sincere account of his own life" in spite of, or perhaps because of, "the narrowness of [his] experience." ${ }^{3}$ Yet such a reading conflicts with another aspect of Thoreau's writing: his commitment to the role of a "lusty Chanticleer" whose job is to wake up his fellow New Englanders from a smug yet unenlightened existence. More specifically, approaching $A$ Week as a pastoral elegy one can hardly explain why Thoreau includes in it pages upon pages of indignant and satirical comments on the dispossession of the Native Americans and on the industrialization of the Merrimack. $A$ Week is not unrolled in a timeless Eden but in the historicized landscape of New England.

2 See Paul, The Shores of America: Thoreau's Inward Exploration (Urbana: Univ. of Illinois Press, 1958), pp. 199, 198; Harding, "Introduction" to A Week on the Concord and Merrimack Rivers, ed. Walter Harding (New York: Holt, Rinehart and Winston, 1963), p. viii; Johnson, Thoreau's Complex Weave: The Writing of "A Week on the Concord and Merrimack Rivers, " with the Text of the First Draft (Charlottesville: Univ. Press of Virginia, 1986), pp. 41 , 44; Lebeaux, Thoreau's Seasons (Amherst: Univ. of Massachusetts Press, 1984), pp. 4, 7; and Peck, Thoreau's Morning Work: Memory and Perception in "A Week on the Concord and Merrimack Rivers," the Journals, and "Walden" (New Haven: Yale Univ. Press, 1990), pp. 3-21.

3 Thoreau, Walden, ed. J. Lyndon Shanley (Princeton: Princeton Univ. Press, 1971 ), p. 3 . 
Analyzing the complex landscape representation in Thoreau's first book, I wish to argue that $A$ Week is a critique of the American pastoral tradition. I read the book from a geographical perspective, for according to Henry C. Darby, a twentiethcentury British geographer, "to explain the landscape" is "the purpose of geography." 4 However, critics who traditionally regard Thoreau as not only a major voice in American literature but also "an heir of . . . the emerging natural sciences" usually treat him as a natural historian; none, to my knowledge, has examined Thoreau's knowledge and use of the geography of his time. ${ }^{5}$ In this essay I will explain why geography as a scientific subject may shed new light in our effort to understand Thoreau better.

Geography, according to Robert E. Dickinson and O.J.R. Howarth, two renowned geographers of the twentieth century, is both the description of the earth and the science about the interrelation between nature and humans. "As the description of the earth," they point out, geography "is the oldest" science in the record of civilization; "as the science of the interrelations between man and his environment," however, it is still "one of

${ }^{4}$ Quoted in Michael Williams, "Historical Geography and the Concept of Landscape," Journal of Historical Geography, 15 (1989), 92.

${ }^{5}$ Joan Burbick, Thoreau's Alternative History: Changing Perspectives on Nature, Culture, and Language (Philadelphia: Univ. of Pennsylvania Press, 1987), p. 3. See also William Ellery Channing, Thoreau the Poet-Naturalst, with Memornal Verses, New Edition, ed. F. B. Sanborn (Boston: Charles E. Goodspeed, 1902); James McInstosh, Thoreau as Romantic Naturalist: His Shifting Stance toward Nature (Ithaca: Cornell Univ. Press, 1974); John Hildebidle, Thoreau: A Naturalist's Liberty (Cambridge, Mass.: Harvard Univ. Press, 1983); and Robert D. Richardson, Jr., "Thoreau and Science," in American Literature and Sccence, ed. Robert J. Scholnick (Lexington: Univ. Press of Kentucky, 1992), pp. 110-27. Joan Burbick, however, anticipated me in noticing the importance of landscape description in $A$ Week. She argues in Thoreau's Alternative History that $A$ Week is both a geographical description and historical narrative about the small corner of northeastern Massachusetts and southern New Hampshire. As early as in his first book, Burbick argues, Thoreau develops "the art of description as the only means to present a correct history of the landscape" (p. 11). But while Burbick emphasizes Thoreau's "alternative" representation of history, I also stress Thoreau's geographical insight in his study of "sequent occupance" of the two river valleys. William Rossi's study of Thoreau's poetic appropriation of Lyell's geological principles is ground-breaking (see Rossi, "Poetry and Progress: Thoreau, Lyell, and the Geological Principles of A Week," American Literature, 66 [1994], 275-30o). Yet Rossi's focus on geology does not include the important impact of new geography on Thoreau's mind. 
the youngest ... sciences" of our time ${ }^{6}$ By both its oldest and newest definitions, geography is one of the main concerns of Thoreau. His major works-A Week, Walden, Maine Woods, and Cape Cod-can be read as, among other things, geographical descriptions of nineteenth-century New England. Running through these works is his attempt to experience nature directly so as to attain and represent a transcendental vision of the ideal interrelation between humankind and the natural environment. Rather proud of his geographical activities, Thoreau claims that he "travelled a good deal in Concord," portrays himself as "self-appointed inspector of snow storms and rain storms," and "surveyor . . of forest paths and all across-lot routes" (Walden, pp. 4, 18). Indeed, he surveyed land, lakes, and rivers; went on excursions; drew maps himself and commented on maps drawn by his predecessors and contemporaries; and read carefully works by such geographers as Humboldt, Guyot, and Lewis and Clark!

Geography as a scholarly discipline was undergoing a paradigm shift in Thoreau's lifetime. As Richard Hartshorne argues, modern geography began with Alexander von Humboldt and Carl Ritter, two German scientists who, in the early half of the nineteenth century, established their theoretically selfconscious "new geography" in a number of monumental works. ${ }^{7}$ Their geography was "new" in that they refused to take geography as a mere collection of sketches of unconnected places on the earth. They wanted "to comprehend all the phenomena of physical objects in their general connexions and to represent nature as one great whole." ${ }^{8}$ Their emphasis on interconnection, their world picture in which humankind is but a part, and

${ }^{6}$ R. E. Dickinson and O.J.R. Howarth, The Makıng of Geography (Oxford: Clarendon Press, 1933), p. 138. I am aware of the sexist language in this quotation and other quotations in the present essay from Thoreau and other nineteenth-century authors. While I avoid using gender specific pronouns, I don't attempt to make anachronistic corrections of older texts.

7 See Hartshorne, The Nature of Geography: A Critical Survey of Current Thought in the Light of the Past (Lancaster, Penn.: Association of American Geographers, 1939), esp. pp. $38-61$.

8 Alexander von Humboldt, preface to Cosmos, quoted in Dickinson and Howarth, Making of Geography, p. 146. 
their insight that landscape is shaped by human activities as well as natural forces all appealed strongly to Thoreau the transcendentalist. Their theory supplemented what Thoreau felt was lacking in the naturalist's narrower perspective.

Thoreau was especially familiar with the work of Alexander von Humboldt. About a decade before Mrs. Sabine translated into English Humboldt's first multivolume work, Personal Narrative, Thoreau showed some knowledge about the German geographer's work in the Andes. Later, in 1848, the year before $A$ Week was published, Thoreau copied long passages from the Personal Narrative. Sometime in the $185^{\text {os }}$ Thoreau acquired and read Humboldt's most comprehensive work, Cosmos, and between $185^{\circ}$ and 1853 he read at least two versions of Humboldt's Aspects of Nature. Aspects was so important to Thoreau that when he felt necessary to explain his relation with the emerging sciences, he named it as one of the two sources of scientific influence on himself:

I am an observer of nature generally, and the character of my observations, so far as they are scientific, may be inferred from the fact that I am especially attracted by such books of science as White's Selborne and Humboldt's "Aspects of Nature."

(Correspondence, p. 310$)^{9}$

Despite Thoreau's own acknowledgment of his indebtedness to Humboldt, I am not interested so much in a source/ influence study here as in an interdisciplinary attempt to examine Thoreau's $A$ Week from a geographical perspective and to see how Thoreau appropriated the most advanced geographical theory of his time in his effort to discover, or dismiss, the

\footnotetext{
${ }^{9}$ Noticing the important role Natural History of Selborne plays in the shaping of Thoreau's attitude toward science, Robert D. Richardson, Jr., chooses Gilbert White as one of the major figures in his study of Thoreau and science. For some reason, Richardson excludes from his list of twenty-odd scientists Alexander von Humboldt, whose influence on Thoreau is as great as that of White, whom Richardson lists (see "Thoreau and Science"). In this paragraph and the two paragraphs preceding it, I draw on Ning Yu, "Thoreau and the New Geography: The Hydrological Cycle in 'Ktaadn,'" ESQ: A Journal of the American Renaissance, 40 (1994), 113-38.
} 
possibility of resolving his problem with John's sudden death in the pastoral tradition.

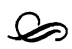

In his formalistic analysis of $A$ Week Sherman Paul skips over the opening chapter, "Concord River." Yet the chapter is rich in suggestions, and it provides a "map" of Thoreau's meandering prose about the river voyage he and John made in 1839. A survey of Thoreau's representation of the New England aquatic landscapes may very well start with this "map."

"Concord River" can be regarded as a map because of its detailed description of the river valley's physical geography. It is also a thematic map of the book, offering clues to Thoreau's insightful social study of transformation of the Native-American, Colonial, and modern-industrial landscapes. Furthermore, as a map, it leads to some early hints about where Thoreau's personal faith lies concerning possible resolutions about the untimely death of his brother and best friend, John.

In the very first paragraph of the chapter, Thoreau identifies the sources of Sudbury River and Assabeth River, two major tributaries of the Concord, traces them to their confluence at the south part of the town of Concord, and then describes the course of the river through Bedford, Carlisle, and Billerica until it "empties into the Merrimack at Lowell." ${ }^{10}$ In this opening chapter Thoreau demonstrates prowess at solidifying the foundation of the factual before building the symbolic upon it.

Thoreau does not stop at the physical level in his geographical description. Soon the cultural implications of the watershed landscapes emerge in a meaningful spatial relationship: located around the town of Concord is a landscape typical of an agricultural community, with some scenes reminiscent

10 Thoreau, $A$ Week on the Concord and Merrimack Rivers, ed. Carl F. Hovde, William L. Howarth, and Elizabeth Hall Witherell (Princeton: Princeton Univ. Press, 1980), p. 6. Further references to this work appear in the text. 
of the pastoral ideal. Near Sudbury, the next town upstream to the southwest of Concord, there are "great hills, and a hundred brooks, and farm-houses, and barns, and hay-stacks" (p. 7). Farther upstream, in the southwest backcountry of Sudbury, we see a landscape of wild nature evoking the American West with broad meadows that look "like a smaller Lake Huron" (p. 6).

Downstream from Carlisle through Billerica, however, a series of dams along the river and the factories at Lowell lend the landscape an industrial feature. Yet, sometimes in the midst of and sometimes underneath the agricultural and industrial landscapes, we see traces of "an extinct race" that has a stronger claim to the river valley because originally this place was "where they hunted and fished" (p. 5). The Concord itself is compared to "an Indian warrior" whose "moccasined tread" is the metaphor for the quiet flow of the river "ceaselessly rolling through the plains and valleys of the substantial earth" (p. 11).

The spatial relation among the three cultural landscapes-agricultural Concord at the center, facing the industrial growth downstream and leaning on the wild nature upstream in Sudbury and Wayland for support, and both the agricultural and industrial over the aboriginal-is highly suggestive. In the light of new geography, Thoreau sees the various stages of cultural development as parts of the larger network of nature. Against the interplay of the natural and man-made landscapes, Thoreau conducts an original kind of geographical study that twentieth-century geographers later named the study of "sequent occupance." 11

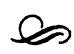

In $A$ Week the pastoral is a prominent feature of the Concord plain. The way Thoreau positions the topo-

${ }^{11}$ In 1929 Derwent Whittlesey described the geographical study of the processes of change in an area caused by human occupance as the study of "sequent occupance." It is interesting that his focus was also New England: "Each generation of human occupance is linked to its forbear and to its offspring, and each exhibits an individuality expressive of mutations in some elements of its natural and cultural characteristics. Moreover, the life history of each discloses the inevitability of the transformation from stage to stage" ("Sequent Occupance," Annals of the Association of American Geographers, 19 
graphical entities in the opening chapter is typically pastoral: the river flows through "great hills, and a hundred brooks, and farm-houses, and barns, and hay-stacks" (p. 7); the houses of the inhabitants, "gray and white" in color (p. 1o) and scattered "along the Sudbury shore, which rises gently to a considerable height, command fine water prospects" (p. 6). This picture has many parallels with what Leo Marx describes in The Machine in the Garden as "the cardinal image" of the American pastoral since the Jeffersonian age:

Although it probably shows a farmhouse or a neat white village, the scene usually is dominated by natural objects: in the foreground a pasture, a twisting brook with cattle grazing nearby, then a clump of elms on a rise in the middle distance and beyond that, way off on the western horizon, a line of dark hills.

(p. 141)

Thoreau uses the pastoral tradition deliberately. In a reminiscence about a summer trip in the Berkshire Hills he evokes the tradition by quoting a passage from Spenser's The Faerie Queene as an illustration of his own experience of the pastoral scene at the western terminus of the Shelburne Falls Valley, which is located at Greenfield, Massachusetts (see p. 203).

In addition to sketching the pastoral scenery Thoreau humorously presents his neighbors, Emerson and Hawthorne, as poetic shepherds in the idealized garden landscape. Quoting Emerson's "North Bridge," Thoreau refers to his mentor as "a Concord poet" who has elevated the "peaceful pasture ground" of Concord village to the poetic height of any Arcadia (pp. 1718). And as the conventions of the pastoral prescribe, in Concord too the "aged shepherd" is assured of the perpetuation of his virtue and talent by the emergence of a new poet-shepherd, "our Hawthorne in the dale" (pp. 18-19).

[1929], 163). Of course, there is an essential difference between Thoreau's landscape study and the twentieth-century study of sequent occupance. Whittlesey and other geographers searched and invented a geographical study against the "environmental determinism" that had dominated American geography since the late nineteenth century. Thoreau, in contrast, depicted the interaction among the cultural landscapes only to show that nature had the final say in the shaping of land. 
Not all the people who spend their lives in the pastoral scenery are able to see the world as a bucolic paradise, however, where they can stay free from the drudgery of the mundane life and enjoy their pastoral existence in the light of poetry. In the paradisiacal valley in Mount Greylock, Thoreau encounters someone who at first looks like an old poet-shepherd but turns out to be a hypocrite. At first glance the old man of Mount Greylock is reminiscent of the older Concord poet, yet when Thoreau asks him for help, rather than practicing the fundamental Christian doctrine of charity that one should help a lost traveler, the old man recites biblical dogmas to get rid of Thoreau (see pp. 208-9).

That the idealized rustic environment does not guarantee ideal inhabitants of a pastoral vision is already foreshadowed in the opening chapter, in a passage where Thoreau describes the daily lives of the Concord farmers, echoing Thomas Gray's "Elegy Written in a Country Churchyard":

[They could be] greater men than Homer, or Chaucer, or Shakespeare, only they never got time to say so; they never took to the way of writing. Look at their fields, and imagine what they might write, if ever they should put pen to paper. Or what have they not written on the face of the earth already, clearing, and burning, and scratching, and harrowing, and plowing, and subsoiling, in and in, and out and out, and over and over, again and again, erasing what they had already written for want of parchment.

This passage can be divided into two parts, the first speculating upon what the farmers could have done on paper, the second describing what they have done in the fields. The first part is a clear echo from Gray and encourages readers to understand it as a praise of the silent but nonetheless poetic farmers of Concord; the rhetorical scheme of the second part, however, challenges the pastoral theme in the preceding lines, urging readers to interpret Thoreau as a social satirist who questions the same farmers' obsessions with the earthly endeavor and thereby their failure to fulfill their higher potentials; they are almost soulless in their relation with God. Thoreau's exaggerated use of polysyndeton subverts the simple lifestyle in the pastoral world: 
the ridiculous proliferation of conjunctions, present participles, and adverbs slows down the movement of the sentence to the degree of boredom, forcing readers to question whether the farmers deliberately choose a monotonous lifestyle or passively remain in a "quiet desperation" because, having been corrupted by their own greed for more profit from commercial farming, they know no other use for their lives.

Of course, in what Leo Marx calls the "complex" pastoral tradition there is always a counter-element to balance the reader's appreciation of an idealized world. ${ }^{12}$ Yet Thoreau's presentation of the dwellers in the American Arcadia as dumb and hypocritical challenges the pastoral ideal to an unprecedented degree from within that tradition. His presentation of the New England pastoral as laid on top of and thus burying the Native-American landscape challenges the tradition itself. It undermines the validity of the American pastoral typically presented by Crevecoeur and critically analyzed by Leo Marx.

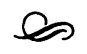

Underneath the rustic topography of New England lies a landscape filled with memories of the values of another race-the Native Americans. ${ }^{13}$ The existence of such a landscape, or rather Thoreau's unearthing of it, poses a moral question about the agricultural landscape as the site of the pastoral Utopia.

In the first sentence of the first chapter of his first book, Thoreau refers to his hometown river by its Indian name, which had been suppressed since the advent of the colonial agriculture: "The Musketaquid, or Grass-ground River, though

${ }^{12}$ See Marx, esp. pp. 88-89; for the distinction between the two kinds of pastoralism, see Marx, pp. 5-11, 24-33.

${ }_{13}$ Though widely recognized as "Concord's leading Indian expert and defender," Thoreau is nevertheless biased by the nineteenth-century stereotype of the Native American only as a hunter and fisherman, especially in $A$ Week (see Robert Sayer, Thoreau and the American Indians [Princeton: Princeton Univ. Press, 1977], pp. ix, 4, 7). However, because my focus is on Thoreau's metaphorical use of geography rather than on how incorrect he is in understanding and representing Native-American culture, I use the term "Indian landscape" as Thoreau projected it-a favorable alternative to the white man's farm. For a critique of Thoreau's concept of Native Americans, see Sayer. 
probably as old as the Nile or Euphrates, did not begin to have a place in civilized history, until the fame of its grassy meadows and its fish attracted settlers out of England in 1635 , when it received the other but kindred name of Concord from the plantation on its banks" ( $A$ Week, p. 5 ). Thoreau's message is clear: by highlighting the relation between the Euramerican's geography and territorial expansion, he shows that the white settler's advance in North America means the displacement of the natives; the Grass-ground River disappears the minute it is written into the "civilized history," though both the grass-ground and the river survive under another name to become owned property of the newcomers.

In the conflict between the aboriginal race and the agricultural society, Thoreau from the beginning sides with the indigenous people, first on the level of language: he thinks that the river is more "properly named Musketaquid, or Meadow River, by the Indians" (p. 9). To support this statement Thoreau cites the 1831 official "valuation" that "there were in Concord two thousand one hundred and eleven acres, or about oneseventh of the whole territory, in meadow" (p. 9). Because the indigenous name of the river is closer to natural facts, Thoreau, using the language of the Indian treaties, suggests that it would outlast the European name: "It will be Grass-ground River as long as grass grows and water runs here; it will be Concord River only while men lead peaceable lives on its banks" (p. 5). The appropriateness of the native name is almost unconditional; as "a transcendentalist, and a natural philosopher to boot" 14 Thoreau has ultimate faith in the regenerating power of nature, and for him water will always run and grass will always grow. By contrast, the colonial name is culturally conditioned; it is subjected to two questions: have the farmer-settlers ever lived peaceable lives? and how long can they stay in peace and harmony with nature and themselves? In his attempt to answer these questions Thoreau converts a relatively static pastoral representation into a dynamic landscape study.

The native landscape is often suppressed and buried underneath what looks like the pastoral geography of the white

14 Thoreau, The Journal of Henry David Thoreau, ed. Bradford Torrey and Francis H. Allen, 14 vols. (Salt Lake City: Gibbs M. Smith and Peregrine Smith Books, 1984), V, 4 . 
settlers. Gliding "over the broad bosom of the Merrimack, between Chelmsford and Dracut" (p. 8o), the Thoreau brothers learn from their gazetteer that they are passing through "an old battle and hunting ground" of the Indians (p. 82). Yet no apparent traces are left about that "ancient dwelling-place of a race of hunters and warriors." Thoreau has to use his talent in field exploration to unearth relics of the aboriginal tribes in that area: "Their weirs of stone, their arrowheads and hatchets, their pestles, and the mortars in which they pounded Indian corn before the white man had tasted it, lay concealed in the mud of the river bottom" (p. 82).

There is another kind of excavation Thoreau has to perform, however, before he can recover the suppressed aboriginal landscape. The native name for Billerica, for instance, is Shawshine, but the white settlers simply ignored it and renamed the place "from the English Billericay" (p. 5o). Here I must quote Thoreau at length in order to delineate adequately his attitudes toward the white man's erasure of the native landscape from the surface of the region. In "Sunday" Thoreau depicts the "Saxon pioneer[s]" (p. 54) as invaders who changed the landscape and chased away the natives:

Some spring the white man came, built him a house, and made a clearing here, letting in the sun, dried up a farm, piled up the old gray stones in fences, cut down the pines around his dwelling, planted orchard seeds brought from the old country, and persuaded the civil apple tree to blossom next to the wild pine. . . And thus he plants a town. The white man's mullein soon reigned in Indian corn-fields, and sweet scented English grasses clothed the new soil. Where, then, could the Red Man set his foot? The honey bee hummed through the Massachusetts' woods, and sipped the wild flowers round the Indian's wigwam, perchance unnoticed, when, with prophetic warning, it stung the Red child's hand, forerunner of that industrious tribe that was to come and pluck the wild flower of his race up by the root.

(pp. 52-53)

The founder of the New England Eden is presented as a proverbial greedy person who would ask for a mile if you gave him an inch: he came and built a house, and then cleared and dried a farm, expanding the space he "owned"; and then he "planted a town," covered the land with "English grasses," and 
named it Billerica so that the native place, Shawshine, no longer existed on his map. In contrast to "the young pines springing up in the corn-fields" (p. 55), which symbolizes the wild strength of the native way of life, the farmer planted the apple trees in the Indian's hunting ground and thus symbolically preconditioned his second fall, from the Eden of North America.

In the conflict between the native's and the settler's efforts to shape New England topography according to their different cultures, Thoreau is again sympathetic to the native. We can sense Thoreau's anger at the white man through his rhetorical question: "Where, then, could the Red Man set his foot?" Native Americans could only go farther north and west, of course. In an emphatic pattern of repetition, Thoreau describes how the aboriginal hunters lost their grounds to the settlers:

The white man comes, pale as the dawn, with a load of thought, with a slumbering intelligence as a fire raked up, knowing well what he knows, not guessing but calculating. . . . He buys the Indian's moccasins and baskets, then buys his hunting grounds, and at length forgets where he is buried, and plows up his bones. And here town records, old, tattered, time-worn, weather-stained chronicles, contain the Indian sachem's mark, perchance, an arrow or a beaver, and the few fatal words by which he deeded his hunting grounds away. (p. 53)

As soon as they turned the native's hunting ground into a pastoral garden, the settlers reinforced the dominance of their version of New England geography through language, signing legal documents and assigning European names to places that already had native names ages before their own arrival:

He comes with a list of ancient Saxon, Norman, and Celtic names, and strews them up and down this river,-Framingham, Sudbury, Bedford, Carlisle, Billerica, Chelmsford,- and this is New Angle-land, and these are the New West Saxons, whom the Red Men call, not Angle-ish or English, but Yengeese, and so at last they are known for Yankees. (p. 53)

Thoreau's record of the white man's verbal possession of the land allows readers to see the conflict between the pastoral and 
the native landscapes as a result of the farmers' invasion of native territory and their remapping of America.

The settlers' possession of America was more than verbal. Physical landmarks along the rivers, too, reminded Thoreau of the "extinct race" and how their land was wrested away from them. On the bank of the Merrimack near the village of Nashville there is "the figure of an Indian's head" carved in the trunk of "a large tree." This is how Thoreau reads the artificial landmark:

It is related in the History of Dunstable, that on the return of Farwell the Indians were engaged by a fresh party, which they compelled to retreat, and pursued as far as the Nashua, where they fought across the stream at its mouth. After the departure of the Indians, the figure of an Indian's head was found carved by them on a large tree by the shore, which circumstance has given its name to this part of the village of Nashville,- the "Indian Head." (pp. 167-68)

Thoreau also presents a picture of the landscape before the incident: "As late as 1724 there was no house on the north side of the Nashua, but only scattered wigwams and gristly forests between this frontier and Canada" (p. 166). He thus puts the battle in the perspective of territorial conflicts between the settlers and the natives; linking it to King Philip's War, which according to Puritan settlers was fought in the name of God against the pagans, Thoreau challenges the validity of the pastoral myth fabricated out of the violent enterprise of the white colonists. Thoreau quotes a white local historian:

"It was observed by some judicious . . . that at the beginning of the war, the English soldiers made a nothing of the Indians, and many spake words to this effect; that one Englishman was sufficient to chase ten Indians; many reckoned it was no other but Veni, vidi, vici." (p. 168)

The "judicious" may be wrong about the natives' ability as warriors, but they faithfully represent the Veni-vidi-vici attitude of the "Englishman," an attitude that conflicts with the myth of the peaceful garden. Since the Native Americans were by no means "peaceably" exterminated, by Thoreau's definition the 
farmers' way of life can never be called truly pastoral. The Concord River and the seemingly "peaceable" communities representing pastoral Utopia never existed in the real sense. Nor can the myth last very long, for there is another threat to the presence of the pastoral: the threat from industrialization. ${ }^{15}$

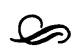

Prominent topographical symbols in $A$ Week of the growing industry are the dams scattered along the Concord River at Concord, Bedford, Carlisle, Billerica, and Lowell, and many more on the Merrimack. These dams signal the beginning of the end of the so-called pastoral in New England landscape: "Its farmers tell me that thousands of acres are flooded now, since the dams have been erected. . . . and they look sadly round to their wood-lots and upland as a last resource" (p. 6). The farmers of that area have every reason to feel "sad" because the growing industrialization threatens to erase the bucolic completely by taking away open land, the matter that makes the pastoral ideal possible in the first place.

The "Corporation with its dam" formed an artificial landmark on the Concord at Billerica, flooding farmers' meadows and keeping the shad from "revisiting their old haunts" (p. 37). Soon "it would seem that the interests, not of the fishes only, but of the men of Wayland, of Sudbury, of Concord, demand the levelling of that dam" (p. 38). Frequently in vain "the farmers stand with scythes whet, waiting the subsiding of the waters, by gravitation, by evaporation or otherwise" (p. $3^{8)}$ ), but it does not take them too long to realize that it is not enough for them just to wait; they must do something to the dam (with "a crowbar," Thoreau advises [p. 37]) against the conspiring "dam proprietors" who used a wider float-board to increase "their already too high privileges" (p. $3^{8}$ ).

The pun reveals Thoreau's anger at the greed of the damn proprietors. Yet he soon shows us that dams and locks on the

\footnotetext{
15 This is Leo Marx's central argument. He remarked, for instance, that "since Jefferson's time the forces of industrialism have been the chief threat to the bucolic image of America" (p. 26). Yet Marx did not notice that Thoreau had made this process a part of his geographical critique.
} 
Concord and Merrimack rivers represent but the older and perhaps milder form of industry. Nature, with the help of time, has been able to absorb the damage that the dams brought to the landscape. Therefore, despite the several dams, the pastoral along the Concord River, though challenged, has not given up its dominant presence in landscape; instead the old dams are given a vernal look by mosses and other creeping plants and thus mingle with the rest of the environment. The true triumph of the industrial landscape begins at the point where the Concord and the Merrimack merge-at Lowell, the factory city that Thoreau calls the "Manchester of America" (p. 83). At this spot, imagining how the river issues "from the iron region of Franconia" (p. 86), Thoreau depicts for his readers a panoramic view of the whole river valley, which to Thoreau's chagrin has been much industrialized:

Standing at its mouth, look up its sparkling stream to its source, - a silver cascade which falls all the way from the White Mountains to the sea,- and behold a city on each successive plateau, a busy colony of human beaver around every fall. Not to mention Newburyport and Haverhill, see Lawrence, and Lowell, and Nashua, and Manchester, and Concord, gleaming one above the other. When at length it has escaped from under the last of the factories it has a level and unmolested passage to the sea, a mere waste water, as it were, bearing little with it but its fame; its pleasant course revealed by the morning fog which hangs over it, and the sails of the few small vessels which transact the commerce of Haverhill and Newburyport. But its real vessels are railroad cars, and its true and main stream, flowing by an iron channel further south.... (p. 87)

From its Anglo-Puritan beginning, as Sacvan Bercovitch points out, American geography "in one sense . . . was historical, in another sense prophetic." ${ }^{16}$ Here Thoreau appeals to both the historical and the prophetic meanings of American geography by evoking the image of a city (or here a series of cities) on a height. The irony is that these actual cities do not really carry the prophetic significance that the Puritans as-

${ }^{16}$ Sacvan Bercovitch, The American Jeremiad (Madison: Univ. of Wisconsin Press, $1978)$, p. 15 . 
signed to New England. The cities are not established according to the word of God but built upon the principle of minimum cost for maximum profits. This is no Massachusetts Bay Colony but "a busy colony of human beaver around every fall." The word "fall" is, again, a pun, suggesting that with this second fall the new occupants of the American Eden have not only demeaned themselves into mindless beasts (beavers) but also disgraced nature by "molesting" the beautiful river and turning it into "a mere waste water."

Yet in another sense, in the dynamic process of landscape evolution, Thoreau's description of the geography of the Merrimack area is truly prophetic. At that particular spot on the river he sees that only a small section of the pastoral riverscape remains "level and unmolested." And even on this small section "small vessels" transact commerce on the water and the true vessels, the railroad cars, shuttle along the "iron channel" between Lowell and Boston. In contrast, the major part of the river has been transformed into a corridor for industry and commerce, characterized by the "iron region"-the dams, locks, canals, canal boats, railroads, and factories.

As the industrialization process accelerated in nineteenthcentury New England, new images appeared on the rivers to compete for the domination of the landscape. In this competition, pastoralism in and of itself was no match for the powerful and violent industrialism; the pastoral landscape receded as industry advanced, and it was reduced to a smaller area by the speedy appearance (and disappearance) of the canals, canal boats, and steamboats that commercialized the riverscape. Finally, the railroad replaced the other industrial landmarks as well as the pastoral ones. Thoreau had noticed on the Merrimack what Mark Twain noticed on the Mississippi decades later:

Since our voyage the railroad on the bank has been extended, and there is now but little boating on the Merrimack. All kinds of produce and stores were formerly conveyed by water, but now nothing is carried up the stream. ... The locks are fast wearing out, and will soon be impassable, since the tolls will not pay the expense of repairing them, and so in a few years there will be an end of boating on this river. The boating, at present, is prin- 
cipally between Merrimack and Lowell, or Hooksett and Manchester. (p. 213)

In addition to the revolution in transportation, new factories mushroomed in the Merrimack valley to help change the appearance of the river. In the summer of 1848 , one year before he published $A$ Week, Thoreau made a walking tour in southern New Hampshire with Ellery Channing, covering some of the areas that he and John had traveled through nine years before. Thoreau incorporated into the final draft of $A$ Week some of the materials he collected during this tour, which reflected how fast the river had changed since 1839 . With John, Thoreau noticed the beginning of an industrial town at the mouth of Piscataguoag, which emptied into the Merrimack: "Just above the mouth of this river we passed the artificial falls where the canals of the Manchester Manufacturing Company discharge themselves into the Merrimack" (p. 245). Not liking what they saw there, the Thoreau brothers "did not tarry to examine [the scene] minutely" but made "haste to get past the village here collected, and out of hearing of the hammer which was laying the foundation of another Lowell on the banks."

Nevertheless, the image of the incipient manufacturing center stuck in Thoreau's mind, and he compared this early picture with the look of the full-grown industrial town nine years later when he revisited it with Channing:

At the time of our voyage Manchester was a village of about two thousand inhabitants, where we landed for a moment to get some cool water. . . . But now, as I have been told, and indeed have witnessed, it contains fourteen thousand inhabitants.

(p. 245)

These new factories, together with the dams, locks, canals, canal boats, and railroads along both rivers, form an emerging but powerful landscape, crowding the banks and threatening to squeeze the pastoral out of the picture. As the agricultural settlements had replaced the aboriginal hunting and fishing grounds, modern industry was rapidly replacing the agricultural presence along the rivers. If the conflict between the 
so-called pastoral landscape and the native one shows that from the start the European settlers' agricultural community was not peaceably established and that its pastoral appearance was achieved by violent deeds as well as violent words, the fastexpanding industrial landscape indicates that the myth of the American pastoral cannot last very long.

Such a doomed fabrication can hardly help Thoreau resolve his problem of human mortality; hence a fundamental question about the nature of Thoreau's first book: despite his use of the pastoral conventions, can we rightfully regard $A$ Week as a pastoral book? It is more accurate to call the book a counter-pastoral work, for on the one hand, in the actual geography of New England, Thoreau shows us that the pastoral landscape has no true past because its violent beginnings contradict the definition of the pastoral; on the other hand, he foresees no future for a pastoral myth that is quickly disappearing before the encroachment of industrialization.

Thoreau did not trust the cultural institution of the pastoral but dramatized the conflicts of three types of New England landscape and sought a resolution of the conflicts in a fourth and by far the most powerful landscape, a wild nature before which the native, pastoral, and industrial models contest for a dominant presence. In $A$ Week the force of wild nature represented by the high flood of the rivers eventually would swallow up human dramas and render them petty and irrelevant.

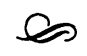

Nature in $A$ Week does not exist in a separate space from the pastoral, the industrial, or the native; it exists, instead, securely behind all three contending landscapes, temporarily giving in to human encroachment but ultimately promising a triumph over human problems. The Great Meadows area of Concord, for instance, is a place where the three cultural landscapes clash but nature reclaims with final serenity: the swampy lowland in the northeast corner of Concord had been the fishing ground for the Indians, but the white farmer bought and owned it as property; the "dam proprietors," however, encroached upon the farmer's "right" by flooding it with 
an extra-wide "new float-board." Yet when the Thoreau brothers paddled round "the neighboring bend" from Concord village into the Great Meadows in 1839, they found that nature still had the upper hand there; whether used as fishing ground or meadow or flooded by the dam proprietors, Great Meadows remained a level, "fertile and juicy place in nature" (p. 19).

The natural landscape is omnipresent in the book, and readers feel its presence not only in Concord, where Thoreau's journey started, but also in "New Concord," the farthest spot the boat carried the brothers. At "the limit of our voyage" (p. 299) Thoreau describes a personal experience in a watersaturated landscape similar to the Great Meadows: "I can fancy that it would be a luxury to stand up to one's chin in some retired swamp a whole summer day, scenting the wild honeysuckle and bilberry blows, and lulled by the minstrelsy of gnats and mosquitoes! ... Surely one may as profitably be soaked in the juices of a swamp" (p. 30o). Thoreau's study of a healthy and reassuring nature helps him and his readers to expand their view of life from an anthropocentric perspective to a broader, "new geographical" one that takes into account both the organic and inorganic kingdoms. The element that Thoreau chooses to represent the vitality of wild nature is water, the source of all forms of life and a connecting symbol in the holistic picture of "new geography." Thoreau's actual trip to New Hampshire took two weeks, one of which was spent in the White Mountains. In his literary representation of the journey, however, he focuses on the rivers but leaves out the week in the mountains. Through the dominant presence of water in his natural landscape Thoreau resolves not only his personal problem of the death of a brother but also the disappearance of a race and its culture.

Thoreau supports his confidence in nature by emphasizing the profusion of lives in the two rivers: "It enhances our sense of the grand security and serenity of nature, to observe the still undisturbed economy and content of the fishes of this century, their happiness a regular fruit of the summer" (p. 26). After listing all the fishes in the Concord he ponders on the disappearance of salmon, shad, and alewives, whose migration is blocked from the Concord by the dam and canal at Billerica and the factories at Lowell. Unlike the fishermen of Concord 
who complain about the improper construction of the "fishways" in the dams, Thoreau looks further and trusts that nature will eventually, "after a few thousands of years" (p. 34), overcome industry and restore the normal migratory route for the fishes all the way to the source of the Concord River.

In addition to hoping for nature's ultimate triumph, Thoreau depicts some of the ever-going renaturalizing processes on the Concord and Merrimack rivers. Near Bedford on the Merrimack the brothers have to move through some ancientlooking locks that are already somewhat naturalized by erosion: "These old gray structures, with their quiet arms stretched over the river in the sun, appeared like natural objects in the scenery, and the king-fisher and sand-piper alighted on them as readily as on stakes or rocks" (p. 238; emphasis added). Water can renaturalize industrial scenes in a more powerful manner, and "the works of man are every where swallowed up in the immensity of Nature" (p. 316). This is best shown in Thoreau's expectation of the highest freshet of the Merrimack.

At Tyngsborough, Thoreau sees a nail in an old apple tree behind a farmer's house, marking "one of the greatest freshets

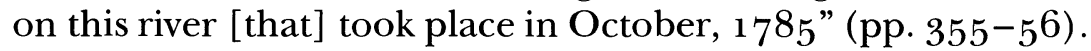
Thoreau is pleased to "learn that there has since been a freshet which rose within nine inches of the rails at Biscuit Brook, and such a freshet as that of 1785 would have covered the railroad two feet deep" (p. 356). Such a freshet would indicate the beginning of nature's triumph and attest that water in $A$ Week functions as something more than the emblem "of human life" (p. 124); it also functions as a powerful agent of nature's selfrejuvenation.

In $A$ Week the process of rejuvenation takes place not so much in the seasonal or diurnal cycle as in the geographical cycle, a term coined by William Morris Davis toward the end of the nineteenth century. But the basic concept of the cycle of geographical transformation is already present in the first book by Thoreau, who probably assimilates it from Charles Lyell's Principles of Geology. ${ }^{17}$ Passing "a large and densely wooded island

17 See Geoffrey J. Martin and Preston E. James, All Possible Worlds: A History of Geographical Ideas, 3 d ed. (New York: John Wiley and Sons, 1993). William Morris Davis established the theory of "geographical cycle" or "cycle of erosion" toward the end of 
this forenoon, between Short's and Griffith's Falls" (p. 243), Thoreau contemplates how the river erodes the banks along its course and deposits the debris somewhere down the stream and thus makes an island. He sees the process of aqueous reproduction as a symbol of the perpetual cycle in which nature renews itself:

An island always pleases my imagination, even the smallest, as a small continent and integral portion of the globe. . . . There is commonly such a one at the junction of two rivers, whose currents bring down and deposit their respective sands in the eddy at their confluence, as it were the womb of a continent. By what a delicate and far-fetched contribution every island is made! What an enterprise of Nature thus to lay the foundations of and to build up the future continent, of golden and silver sands and the ruins of forests. (p. 243)

Thoreau has "a fancy for building my hut on [a small island]" (p. 243), because it enables him to see the "earth" constantly "created or destroyed" (p. 244). Through this specific fact Thoreau sees a general truth of nature's perpetual regeneration: when nature "destroys" something, she is actually using it to "create" the world anew; thus, perhaps after nature levels down the dams "a few thousands years later," she will use the chunks of concrete as foundations of a new continent. Treat-

\footnotetext{
Thoreau's century (first announced in 1884 and published in revised form in 1899). Conducting a geographical survey of the Missouri River for the Northern Pacific Railroad, Davis noted some terraces above the river and interpreted their existence "as the result of the removal of an 'unknown thickness of overlying strata,' and the reduction of an earlier surface close to the baselevel of the drainage" (Martin and James, p. 307). Davis invented a useful set of terminology to explain the interesting phenomena he discovered along the Missouri Valley: "When the initial surface is still undissected between the valleys, when the valleys are V-shaped, and when the rivers descend through them turbulently-this is a stage Davis described as youth. The greatest amount of relief occurs when the last remnant of the initial surface is dissected. Then the surface is gradually reduced, and the valleys begin to widen. This is the stage Davis described as maturity. When the rivers meander across wide valleys and the land between the valleys has been reduced to gently rounded slopes-this he called old age. The upheaved block of the earth's crust is worn down almost to a level plain, which Davis called a peneplain. The whole cycle, Davis pointed out, could start again with another uplift, resulting in rejuvenation" (Martin and James, p. 308). For Lyell's concept of aqueous causes for changes on the surface of the earth, see Rossi, "Poetry and Progress," esp. pp. 279, 297.
} 
ing human affairs as part of the geographical cycle, Thoreau comments:

There is, indeed, a tide in the affairs of men, as the poet says, and yet as things flow they circulate, and the ebb always balances the flow. All streams are but tributary to the ocean, which itself does not stream, and the shores are unchanged but in longer periods man can measure. Go where we will, we discover infinite change in particulars only, not in generals.

(p. 124)

The aqueous causes transform the face of earth in a larger cycle than days and seasons. This larger cycle has the power to absorb the human impact on the earth, and it redeems the death of individuals by including human beings in the whole, organic process of life-death-regeneration. By enacting the dramas of the conflicting cultures in the natural landscape, Thoreau emphasizes the power of nature over that of cultural traditions, including the pastoral elegy. For Thoreau, nature is the "true benefactress, the secret of [whose] service is unchangeableness" (p. 1 14). Thoreau turns to this ultimate unchangeableness as a source of comfort for the loss of a brother, and he criticizes the pastoral tradition in a larger, geographical representation of the shaping of New England. The two New England rivers symbolize for Thoreau something that functions in its own way, something that cannot be reduced to the generic category of the pastoral elegy nor to any other human category. Reading $A$ Week as an Americanized pastoral elegy prevents us from seeing the larger issues in Thoreau's first book; considering $A$ Week as held together only by the "days of the week" (again a cultural category) leads readers to see the book's structure as flawed. In contrast, considering the larger cycles of "sequent occupance" and geographical rejuvenation as major warp and weft in the "complex weave" of $A$ Week, we have reason to argue that Thoreau's first book is, like Walden, a well-structured cultural critique as well as the private resolution of a personal tragedy.

Western Washington University 